\title{
Problematici în America Latină. Contraste socioculturale și reprezentările lor în literatura contemporană
}

\author{
Sorina-Crina Ghiață ${ }^{\star}$ \\ Facultatea de Litere, Universitatea „Alexandru Ioan Cuza”, Bd. Carol I 11, 700506 Iaşi, România
}

\section{Despre articol}

Istoric:

Primit 8 august 2020

Acceptat 3 octombrie 2020

Publicat 27 decembrie 2020

Cuvinte-cheie:

discurs literar

multiculturalism

postcolonialism

identitate

violență

\begin{abstract}
Rezumat
America Latină a însemnat o asociere de paradoxuri inedite, încă din momentul în care s-a declanșat procesul de obținere a independenței tuturor teritoriilor care au fost cîndva colonii și, ulterior, teritorii ultramarine, ale diferitelor state din Europa Occidentală. Portugalia și Spania au dominat în trecut, mai ales din punct de vedere lingvistic, dar și religios, actualul spațiu devenit un mediu cultural variat. În acest context, scopul prezentului studiu este de a surprinde, în partea introductivă, caracteristici ale complexei identităţii latinoamericane (reflectate, spre exemplu, în denumirile asociate acestui spațiu al civilizaţiei, în împrejurările politice și problemele sociale, în special). În plus, o altă finalitate constă în a evidenția felul în care se reflectă aceste aspecte în proza autorilor hispano-americani moderni, Rodrigo Rey Rosa și Héctor Abad Faciolince. Subliniind totodată şi flagelul discriminării sau cel al inechităţilor, dar, mai ales, violența perpetuă, studiul conchide cu o referire (regăsită tot în discursul literar din cele două texte alese pentru analiză, Los sordos și El olvido que seremos) la spiritul etic, dar și la sentimentul de empatie-subiecte abordate de către ambii scriitori-într-o lume care pare tot mai fragmentată și depersonalizată, acaparată parcă de un continuu stigmat al dezechilibrului.
\end{abstract}

\section{Generalități}

Atunci cînd vorbim despre literatura hispano-americană din zilele noastre, ne referim inevitabil la autori care, în operele lor, prin discursul, dar și prin intermediul tematicii adoptate, reflectă problematici fundamentale ale vieții cotidiene din mediul latinoamerican. În ceea ce privește contextul istoric, social, cultural și economic care definește teritoriul sudic al Noii Lumi, America Latină s-a dovedit a fi, încă de la nașterea ei, atît de diferită faţă de alte locuri marcate și transformate în mod definitiv de civilizație, de-a lungul istoriei.

Continentul american a fost, din momentul descoperirii sale și pînă în prezent, o parte a lumii cufundată în campanii de cucerire, în revolte, revoluțiii, războaie, dar și stăpînită de regimuri politice totalitare, referindu-ne, desigur, la țări aflate la sud de Statele Unite ale Americii și în Marea Caraibelor. Putem afirma faptul că acest teritoriu al lumii nu a rămas în afara situaţiilor de criză, nici nu a fost scutit de tumultul istoriei care l-a transformat într-un mediu care abundă de contraste (unele de natură politică, geografică, altele de tip social, mai presus de toate, dar şi cultural).

Pentru mulți istorici, aprecierea spațiului latinoamerican ca avînd o structură omogenă rezultă a fi o misiune aproape imposibilă, ținînd cont de faptul că acesta reprezintă un cumul de naţiuni, de etnii și rase, extrem de divers. Totuşi, există voci ce sunt partizane ideii conform căreia, America nu ar putea exista în afara conceptului de unitate-Dado que, si dicho principio de unidad no existiera, esta historia no sería posible $[\ldots]^{1}$ (Zanatta, 2012, p. 12) —și care, în sprijinul acestei ipoteze, oferă argumente puternice. Unul dintre ele se referă, neîndoielnic, la nenumăratele eforturi în scopul cîștigării independenței.

\footnotetext{
*Adresă de corespondență: sorina.ghiata@yahoo.com.

${ }^{1}$ „Luînd în considerare faptul că, dacă respectivul principiu al unității nu ar exista, această istorie (n.r. - a Americii Latine) nu ar fi posibilă” (t.n.).
} 
Sorina-Crina Ghiață

\subsection{Denumirile asociate spațiului sociocultural latinoamerican}

Dintre țările din Europa care au exercitat o puternică influență lingvistică pe teritoriul Americii Latine, Spania ocupă, cu certitudine, primul loc. Acesta este și motivul pentru care, atunci cînd facem trimitere la statele americane care sunt vorbitoare de limbă spaniolă (și care sunt, de asemenea, majoritare), hispaniștii utilizează adesea mai mulți termeni, între care, Hispanoamérica. Denumirea de Iberoamérica ${ }^{2}$, nu este însă folosită cu aceeași recurență. În afară de această asociere terminologică ce reflectă caracterul unitar al continentului, alte precizări cu privire la termenii atribuiți Americii Australe se referă inclusiv la diversitatea geografică și socioculturală. Dintre acestea menționăm Sudamérica, ce desemnează un referent geografic și face trimitere la statele care se află în sudul istmului Panamá. De obicei, geografii și istoricii descriu două situații care descriu acest aspect al geografiei. Prima dintre acestea se referă direct la istmul Tehuantepec (care realizează legătura dintre America de Nord si America Centrală), iar a doua situație reprezintă o trimitere la istmul Panamá (care unește Americile Centrală și Sudică).

Atunci cînd vorbim despre America Latină care reprezintă un concept cultural, înainte de toate, ar trebui să includem și statul mexican, deoarece istoria Statelor Unite Mexicane, precum și aspectele culturale care le definesc determină alinierea la variata lume latinoamericană. Nu doar multiplele denumiri și multiculturalismul demonstrează gradul de diversitate al continentului american, ci și caracteristicile etnice reprezintă un puternic argument în această direcție. Prin urmare, este indispensabilă mențiunea influenței exercitate dintr-o altă parte a lumii, care îi determină pe istorici, dar și pe lingviști și geografi, să adauge încă un termen, pe cît de elocvent pe atît de necesar caracterizării, precum și înțelegerii diversității continentului american: Afroamérica. Atunci cînd utilizăm acest prefix (afro-), ne referim la moștenirea africană de pe continentul american, dar nu doar la nivel etnic, ci și din punct de vedere cultural—de exemplu, influența asupra manifestărilor artistice și ritualurilor religioase.

\subsection{Aspecte economice, politice și sociale}

Deși America Latină este complexă și diversă, luînd în considerare mai multe perspective, acest fapt nu arată neapărat o lume în care predomină exclusiv aspectele pozitive. Diversitatea exemplificată în subsecțiunea anterioară se dovedește a fi, totodată, dublată de anumite contraste vizibile și de anumiţi factori negativi. Cu privire la aceste contraste, un exemplu este dat de statele Uruguay și Paraguay. Spre deosebire de Paraguay, Uruguay este considerată ca fiind una dintre cele mai dezvoltate țări din mediul latinoamerican, mai ales din punct de vedere economic.

Privitor la aspectul economic menționat anterior, este importantă precizarea faptului că o altă mare discrepanță economică și, prin urmare, socială, s-ar putea evidenția între situația din țările Venezuela și Ecuador (stat sărac în ceea ce privește bogățiile naturale, dar care produce și exportă boabe de cacao). O puternică parte a progresului economic din Venezuela se datorează extragerii de petrol. O relevanță deosebită, care poate alimenta argumentele prosperităţii înregistrate cîndva în Venezuela o are trimiterea la remarcile unei personalități literare remarcabile din America de Sud, Isabel Allende, autoare de origine chiliană. În timpul dictaturii declanșate de către liderul autoritar din Chile, Augusto Pinochet, doi membri din familia lui Allende se refugiază în Venezuela, considerată pe atunci prosperă și sigură, determinîndo și pe scriitoare să-și părăsească țara, refuzînd să mai suporte frica teribilă, prezentă pretutindeni, generată de sistemul toxic, dictatorial, după cum ea însăși a afirmat (Allende, 2004, p. 122).

Un alt contrast important se referă la statele Bolivia și Argentina. Dacă ne uităm la prima dintre aceste două țări alese pentru realizarea comparației, putem afirma că despre Bolivia ni se indică constant un înalt grad de sărăcie și poate că vorbim despre cel mai notabil grad de discrepanţă socială de pe continentul hispano-american, spre deosebire de ceea ce reprezintă Argentina. Aproape că nici nu mai este necesară sublinierea economiei extrem de dezvoltate de care statul dispunea în secolul trecut. Ca și în cazul Uruguay, Argentina și-a consolidat unul dintre cele mai sustenabile sisteme economice la nivel mondial.

\footnotetext{
${ }^{2}$ Se subînțelege, în acest caz și zona care în urmă cu secole a fost cucerită de Regatul Portugaliei-actualul teritoriu al Braziliei.
} 
Această scurtă paralelă reprezintă un exemplu concludent și elocvent, atunci cînd vine vorba despre a reflecta doar un mic capitol din uriașele diferențe care se regăsesc pe teritoriile aceluiași continent, în aceeași zonă geografică și socioculturală a lumii (Siegel, 2016, p. 113-117) .

Însă discrepanțele economice nu sunt singurele care afectează nivelul de trai al populației din America Latină. Nefasta influență a drogurilor (în special a cocainei), dar și plaga populismului reprezintă, de asemenea, factori negativi, care contrastează puternic cu varietatea culturală ce constituie un mare avantaj pentru continentul austral. E relevantă mențiunea că cea mai mare parte a populației din Bolivia, exemplul amintit mai sus, este de origine indigenă și vom urmări modul în care această problematică a amerindienilor se reflectă în romanele analizate.

În zilele noastre putem afirma că, poate cel mai mare flagel care afectează grav această parte a lumii și care se dovedește a fi generator de dezechilibre sociale, este violența: Los indices de homicidio y delito se han incrementado durante 1980 y 1990 en variospaises latinoamericanos ${ }^{4}$ (Aguiar, 2006, p. 115). Crimele, răpirile, amenințările, precum și lumea traficanților de droguri sunt semne ale violenței extreme care se manifestă în interiorul continentului și nu numai. Pentru a clarifica, am putea adăuga drept exemplu, o comparație între America Latină și Europa. Chiar dacă țările europene însumează și ele la rîndul lor caracteristici dintre cele mai diverse din varii puncte de vedere, majoritatea situațiilor întîlnite pe Vechiul Continent nu sunt similare cu ceea ce regăsim în această parte a Noii Lumi. Din nefericire, violența a devenit aproape o amprentă culturală caracteristică.

\section{Preocupări în discursul literar modern}

Referitor la operele literare hispano-americane, $\operatorname{Los}_{\operatorname{sordos}^{5}}(2012)$ este primul text analizat în cadrul acestui studiu și îi aparține lui Rodrigo Rey Rosa, scriitor originar din Guatemala. Romanul are în primplan tematici precum statutul social al unei întregi clase sociale (supuse mereu unor sarcini periculoase, dar și anumitor compromisuri) și, mai ales, tema răpirii. Am spune că trăsăturile de roman „polițist” se contopesc extrem de unitar cu partea realistă a scrierii, dar şi cu ambiguitatea situațiilor, insinuată și de un discurs literar, mai degrabă sugestiv, decît categoric și sentenţios, folosit de către autor. Pe lîngă acestea, maniera în care romanul este conceput, stilul lui Rey Rosa, scriitura augmentează impresia de ambiguitate, creînd secvențe și fragmente care ne conduc mai mult spre ideea de sugestie și de situație deschisă, potențînd chiar și mai mult misterul dacă ne gîndim la faptele unui personaj sau ale altuia. Vom observa în continuare, punctual, la ce figuri epice ne referim.

Unul dintre planurile narative ce constituie romanul lui Rodrigo Rey Rosa are în centru parcursul unui tînăr din Guatemala, Cayetano, care, cu ajutorul unchiului său, devine gardă de corp. Misiunea permanentă a lui Cayetano este acum să o păzească pe Clara, o femeie care pare forțată de tatăl său—figura cea mai autoritară din roman - să fie supravegheată, împotriva voinței sale. Ceea ce ocupă cu certitudine un rol central în opera lui Rey Rosa este marea diferență dintre clasele sociale. Regăsim, de asemenea, într-o puternică opoziție, modul în care autorul construiește prezentarea vieții luxoase trăite de Clara și de apropiații ei, toți membrii acestei familii fiind exponenți ai înaltei societăți, în comparație cu gărzile lor de $\operatorname{corp}^{6}$. Pe de altă parte, autorul originar din America Centrală pune accent în opera sa (utilizînd, de altfel, numeroși termeni în limba spaniolă, dar care provin din idiomul prehispanic maya) și pe un alt chip al

\footnotetext{
${ }^{3}$ Siegel argumentează discrepanțele sociale din America Centrală și de Sud, în contextul geopolitic: „The environmental governance intersects with economic, and more importantly, social development in Latin America [...] the complex issues of achieving sustainable development in Latin America is tied to the region's position in the global political economy and recent changes in relation to this” (2016, p. 113)_, „Patronarea mediului se intersectează cu dezvoltarea economică, dar și cu cel mai important tip de dezvoltare din America Latină, cea socială [...] problemele expansive în a pune bazele unei dezvoltări sustenabile în zonă (n.r.: America Latină) sunt legate de poziția regiunii în peisajul politicii economice, precum și de schimbările survenite recent în acest sens" (t.n.)

${ }^{4}$ "Indicele omuciderii și al delictului a crescut în perioada anilor 1980 și 1990, în mai multe state latinoamericane” (t.n.).

${ }^{5}$ Surzii (t.n.)

${ }^{6}$ Los guardaespaldas.
} 
societății: populația indigenă.

Cel de-al doilea plan narativ are în centrul său o altă figură principală din roman: este vorba despre personajul feminin Clara, fiica unui bărbat înstărit, bancher, dar și situațiile în care cititorii o regăsesc. Un aspect care surprinde mult pare a fi subliniat într-o scurtă mențiune introductivă, în care sunt identificate două personaje dispărute, care provin din clase sociale distincte: Los sordos se inicia con dos desapariciones: la de un niño sordo en un pueblo del interior guatemalteco y la de Clara, hija de un banquero rico y «amable tirano». ¿Hay alguna conexión entre ambos hechos? ¿Qué papel juegan Javier, amante de Clara y abogado de la familia, los guardaespaldas de Clara y de su padre, y los médicos que dirigen un hospital de prácticas sospechosas? ¿Es posible aún alguna forma de amor y de justicia en medio de la violencia? (Rey Rosa, 2012).

$\mathrm{Cu}$ privire la ambiguitatea narațiunii, aceasta ar putea reprezenta punctul forte al romanului, însă, pe lîngă ideea de mister, Rodrigo Rey Rosa dorește să pună în evidență consecințele grave, dezastruoase pentru societate, care rezultă în urma violenței. Scriitorul guatemalez trimite, indubitabil, la morala conform căreia, nimeni nu rămîne scutit de iminența pericolului și agresiunilor la care toți sunt expuși și riscă să devină victime (fără ca statutul social—un copil lipsit de simțul auzului și defavorizat din punct de vedere material, dar și o femeie foarte bogată-să conteze în vreun fel). Poate că una dintre temele secundare ale cărții, temă fixată poate și de elementul paratextual (titlul) se referă la lipsa empatiei. Pe de o parte, descoperim, o dată cu intriganta lectură, faptul că absența acestui sentiment se manifestă față de indigeni (într-o notă ceva mai generală), iar pe de altă parte, față de personajul feminin Clara, în particular. Tatăl ei, extrem de autoritar în relația cu familia sa, o obligă să fie păzită în permanență, pentru a o proteja, dar fără a ține deloc seama de faptul că ea își dorea libertate, fără a fi urmărită pretutindeni.

De altfel, din punct de vedere lingvistic, ne putem gîndi la o percepere ambivalentă a titlului. Citatul amintit mai sus cuprinde cu multă acuratețe esența romanului. Pentru a ne referi la o primă interpretare a pragului textual, în sens propriu, observăm că autorul alege două personaje-cheie, reprezentanți ai unor medii sociale diferite, pentru a se putea referi la evidenta lipsă de empatie faţă de los indios ${ }^{8}$, reflectată în practica care se desfăşoară într-unul dintre locurile destinate realizării unor experimente ilegale, utilizînd copii de origine mayașă. În acest caz, Rodrigo Rey Rosa sugerează faptul că în acest mod ar putea fi expus și respectivul băiat care dispare subit și care nu poate auzi, dar niciodată nu precizează explicit. $\mathrm{O}$ altă interpretare a titlului, în sens figurat de această dată, ar putea face referire la protagonista Clara, personaj pe care ceilalți, în special familia sa (mai cu seamă, tatăl ei) nu îl ascultă, nu îi aud disperarea și, prin urmare, nu îi oferă libertatea de a trăi în felul în care ea și-ar dori.

Conform stilului său caracteristic, autorul inserează episoade scurte (dar care stîrnesc în mod intenționat impresia de ambiguitate și care potențează misterul întîmplărilor), în care este insinuată ideea conform căreia Clara se refugiază, prin voință proprie, într-unul dintre locurile cele mai misterioase, descrise ulterior în roman. Este vorba despre un spital din apropierea unui lac, în care Clara alege să se izoleze. O parte a acțiunii care lasă loc multor interpretări şi care construiește, de asemenea, intriga, ar putea fi reprezentată de atitudinea lui Javier, amantul Clarei, cel care pare să „orchestreze” totul cu privire la „răpirea” ei. De altfel, cele două personaje se află și într-o relație de complicitate.

În altă ordine de idei, acțiunea este plasată într-un cadru ce trezește bănuieli, iar violența mascată domină universul literar al lui Rodrigo Rey Rosa ${ }^{9}$. Scriitorul guatemalez se referă, de fapt, la o tristă realitate, reflectată într-un mod aparte, în textul său: unele dintre instituţiile spitalicești construite în mijlocul pădurilor tropicale din America Centrală servesc drept suport pentru experimentele ilegale, nesigure și îngrozitoare, realizate mai ales pe copii din familii de amerindieni. Situarea acestui loc care devine

${ }^{7}$ „Los sordos debutează prezentând două dispariții: cea a unui copil surd dintr-un sat înrădăcinat în mediul guatemalez şi cea a Clarei, fiica unui bancher bogat și «tiran amabil». Există oare o legătură între cele două întîmplări? Ce rol joacă Javier, amantul Clarei și avocatul familiei, gărzile de corp ale Clarei și ale tatălui său, dar și medicii care conduc un spital banuit că ar găzdui practici suspecte? Este încă posibilă o formă de iubire și de înfăptuire a justiției în mijlocul violenței?” (t.n.)

${ }^{8}$ Amerindienii (t.n.)

${ }^{9}$ Această temă dominantă în imaginarul operei autorului guatemalez se regăsește și în alte scrieri ale sale, precum Cárcel de árboles (1992) sau El material humano (2009)-Închisoarea arborilor; Materialul uman (t.n.) 
pentru autor, pentru narator și, nu în ultimul rînd, pentru cititor, un spațiu aproape „fantastic” ${ }^{10}$, pe malul unui lac, pare că permite cu adevărat scriitorului să întărească structura părții narative care se axează pe obiceiurile, precum și pe felul de a-şi duce existența, al populației mayașe. Observăm în acest sens și faptul că autorul insistă de mai multe ori, atunci cînd vine vorba despre a evidenția contrastul dintre două lumi diametral opuse. În primul rînd, Rey Rosa se referă la lumea tradițiilor și la obiceiurile străvechi, înrădăcinate în imaginarul colectiv indigen, iar în al doilea rînd, trimiterea este făcută la influența civilizației moderne, precum și la capacitatea și forma de adaptare ale acestei populații de origine prehispanică.

Cît privește puterea empatiei, scriitorul guatemalez nu ezită să accentueze flagelul discriminării, tot mai prezent și în zilele noastre, cel puțin în țara sa ${ }^{11}$. Autorul latinoamerican identifică din această perspectivă o problematică, una dintre cele mai grave dificultăți cu care se confruntă țara sa şi consideră că acesta este principalul motiv pentru care astfel de practici medicale atît de condamnate și controversate există. El recunoaște totodată că toate acestea s-au transformat într-o obsesie, ceea ce l-a determinat inclusiv să mediteze cu privire la acest aspect: No tengo idea de cómo nace ninguna obsesión; de pronto eres víctima de una, más bien ${ }^{12}$ (Martinetto, 2012, p. 357).

\section{Confesiunea unei experiențe dramatice}

Un alt roman care îi aparține, de această dată, scriitorului columbian Héctor Abad Faciolince și care se intitulează El olvido que seremos ${ }^{13}$ (2006) are ca temă centrală, iubirea paternă și filială dintre un tată și fiul său. Alte universuri tematice abordate de către autor în scrierea sa au transformat-o într-un text al cărui deznodămînt se dovedește a fi tragic, deoarece, ca și în Los sordos, în centrul acțiunii este de asemenea violența, privarea de libertate, frica, dar și puterea sacrificiului, într-o societate grav afectată din pricina conjuncturii nefaste care a pus stăpînire pe unele țări latinoamericane, în secolul trecut.

În termeni generali, naratorul relatează, la persoana întîi, într-un stil emoționant și personal, o amplă confesiune despre suferința cauzată de pierderea celei mai prețuite și iubite ființe de către copilul Abad: tatăl său. De asemenea, ca și cum această suferință nu ar fi suficientă, Abad a mai pierdut înainte o soră. În afară de descrierea unei relații extrem de strînse pe care fiul o avea cu tatăl și tot ceea ce însemna figura paternă pentru el, descoperim în roman o acțiune care se desfășoară în vremuri extrem de tulburi, probabil cele mai întunecate din istoria Columbiei independente, atunci cînd orașul Medellín era considerat ca fiind locul cel mai riscant, violent și cu un grad uriaș de periculozitate, din lume.

Chipul tatălui, omniprezentă în textul lui Héctor Abad Faciolince reprezintă societatea patriarhală care predomină în America Latină. Dacă am face o scurtă comparație între acest roman și textul lui Rodrigo Rey Rosa, am spune că relația pe care Clara o avea cu tatăl său este foarte diferită faţă de cea care exista între Abad și medic (conform limbajului utilizat de autori, a modului de a descrie aceste legături dintre tată și fiu/fiică). Totuși, în ambele cazuri putem vorbi despre o dominantă paternă—reflectată în text, inclusiv la nivel lexical, după cum vom putea observa în fragmentul din paragraful următorcare exercită o influență, asupra figurii infantile, fie ea pozitivă, în textul scriitorului columbian, respectiv negativă, în romanul lui Rodrigo Rey Rosa.

Legat de puternica afecțiune pe care micul Abad o avea pentru tatăl său, intensitatea sentimentului filial amintește de iubirea și de afecțiunea aproape obsesivă pe care personajul-narator din opera lui Marcel Proust, În căutarea timpului pierdut (o călătorie literară inedită, introspectivă, ghidată de ceea ce poate declanșa memoria afectivă) o simțea pentru mama sa. În romanul lui Faciolince există multe trimiteri care

\footnotetext{
${ }^{10}$ Acest spațiu, misteriorsul spital, ajunge să fie, nu doar în Los sordos, ci și în alte opere precizate, un element care provoacă o spărtură în coerența filonului realist ce contribuie la alcătuirea narațiunii.

${ }^{11}$ Într-un interviu oferit în anul 2012 cotidianului spaniol El País, disponibil online, cu ocazia publicării romanului său, Los sordos, Rodrigo Rey Rosa atrăgea atenția asupra faptul că „în Guatemala se trăiește un 'apartheid' fără legi” —,en Guatemala se vive un 'apartheid' sin leyes" (t.n.).

${ }^{12}$ „Nu reușesc să îmi explic felul în care se nasc obsesiile; dintr-o dată, tu ești, mai degrabă, cel care devine victima unor astfel de trăiri” (t.n.).

${ }^{13}$ Suntem deja uitarea ce vom fi (Abad Faciolince, 2014).
} 
fac referire la acest puternic sentiment, iar una dintre acestea, extrem de elocventă, surprinde o un dialog insolit la care ia parte tînărul Abad:

[...] - Su papá se va a ir para el Infierno.

- ¿Por qué? - le pregunté yo.

- Porque no va a misa.

$-¿ Y$ yo?

- Usted va a irse para el Cielo, porque reza todas las noches conmigo. [...]

- No voy a volver a rezar.

- ¿Ah, no? - me retó ella.

- No. Yo ya no me quiero ir para el Cielo. A mí no me gusta el Cielo sin mi papá. Prefiero irme para el Infierno con él. ${ }^{14}$

(Abad Faciolince, 2017, p. 8).

Dacă am menționat lipsa de empatie—în Los sordos—, violența și sacrificiile personajelor (mai ales dacă ne gîndim la figura tatălui protagonistului) identificate în romanul lui Abad Faciolince, am putea face referire, de asemenea, la documentarul numit Carta a una sombra ${ }^{15}$. Intreaga familie reunită a medicului Héctor Abad Gómez retrăiește momente dureroase, amintind că atît timp cît Héctor a fost în viață, nimeni dintre ei nu a fost defel conștient de riscul pe care și-l asuma cel care a sfîrşit asasinat și ai cărui ucigași nu au fost niciodată găsiți. Totuși, nu ar fi de prisos precizarea că, în cazul membrilor familiei nu putem vorbi despre o „lipsă de empatie”, ci ne-am putea gîndi, mai curînd, la modul în care doctorul dorea să își protejeze semenii iubiți și, de aceea, fără ca aceștia să știe, el lua parte la manifestații pentru libertate, siguranţă, justiție și pentru drepturi. Prin comparație, întrebarea cu privire la realitatea reflectată de acțiunea romanului lui Rodrigo Rey Rosa pare cît se poate de firească și în cazul scriitorului columbian: mai poate fi vorba despre înfăptuirea actului de justiție atunci cînd violența este pretutindeni?

Un alt aspect care merită abordat și care apare foarte bine reprezentat atunci cînd vine vorba despre a realiza o paralelă între două romane, este legat de rolul medicinei, care a declanșat, după cum am putut observa, o obsesie în cazul scriitorului Rodrigo Rey Rosa, dar care este expus într-o manieră extrem de distinctă atît în opera autorului columbian, cît și în documentarul amintit, prin intermediul chipului patern sau, mai bine zis, prin statutul său social. În Los sordos, un spital aflat în mijlocul pădurii tropicale și în care se realizau, probabil, experimente ilegale, periculoase și neautorizate este tocmai ceea ce se opune în mod categoric ideologiei bazate pe spiritul etic și pe buna voință, virtuți care îl caracterizau pe medicul Héctor Abad Gómez.

\section{Concluzii}

Pentru a concluziona, este importantă mențiunea faptului că cele două texte abordate în studiul de față reflectă, pe de o parte, în mod elocvent, elemente ce alcătuiesc varietatea socioculturală care definește America Centrală și de Sud. Pe de altă parte, cei doi autori surprind în romanele lor o realitate dureroasă ce caracterizează națiunile latinoamericane.

Am observat, aşardar, încă o dată, în momentul realizării acestui articol, paradoxul creat de factorii care reușesc să aducă împreună civilizațiile Americii Latine, dar și de aceia care le despart și care generează deficiențe în afirmarea identității. Cel mai amenințător flagel rămîne în continuare violența, denunțată aproape de fiecare dată de către reprezentanții literaturii postcoloniale.

\footnotetext{
${ }^{14}$ „[...] - Tatăl tău va merge în iad./- De ce? - am întrebat eu./ - Pentru că nu participă la slujbă./ - Și eu?/ - Tu vei merge cu mine în Rai, pentru că te rogi în fiecare seară împreună cu mine. [...]/ - Nu voi mai spune rugăciuni./ - A, nu? - mă provocă ea./ - Nu. Nu mai vreau să merg în Rai. Nu m-ar încînta Raiul fără tatăl meu. Mai bine mă duc în iad, cu el” (t.n.).

${ }^{15}$ Scrisoare unei umbre-t.n., disponibil online.
} 


\section{Bibliografie}

Abad Faciolince, H. (2014). Suntem deja uitarea ce vom fi (trad. Mariana Sipos), Curtea Veche, București.

Abad Faciolince, H. (2017). El olvido que seremos, Alfaguara, Madrid.

Aguiar, J.C.G. (2006). Las politicas de seguridad pública en América Latina: policía, violencia y narcotráfico en México, în „European Review of Latin American and Caribbean Studies”, 81, p. 115-121, Crossref.

Allende, I. (2004). My Invented Country, A Memoir (trad. Margaret Sayers Peden), Harper Perennial, New York.

Barceló, R., Sánchez, M.J. \& Portal, M.A. (coord.) (2013). Diversidad étnica y conflicto en América Latina, II. El indio como metáfora en la identidad nacional, Plaza y Valdés Editores, Madrid.

De la Torre, C. (2013). In the Name of the People: Democratization, Popular Organizations, and Populism in Venezuela, Bolivia, and Ecuador, în „European Review of Latin American and Caribbean Studies”, 95, p. 27-48, Crossref.

Gutiérrez de MacGregor, M. T. (2009). La Geografía en América Latina: visión por paises, în „Investigaciones geográficas”, 69, [online].

Klein, M. (2003). The Human Rights Violations of the Pinochet Regime and Their Legacy, în „European Review of Latin American and Caribbean Studies", 74, p. 107-114, Crossref.

Kruijt, D. (2003). Post-War Central America, în „European Review of Latin American and Caribbean Studies”, 75, p. 119-126, Crossref.

Manzoni, C., (ed.) (2005). Violencia y silencio: literatura latinoamerica contemporánea, Corregidor, Buenos Aires.

Martinetto, V. (2012). Breve entrevista a Rodrigo Rey Rosa, în „Revista de literatura hispánica”, 1 (75), p. 357.

Rey Rosa, R. (2012). Los sordos, Alfaguara, Madrid.

Siegel, K.M. (2016). Environment, Politics and Governance in Latin America, în „European Review of Latin American and Caribbean Studies", 102, p. 109-117, Crossref.

Suselbeck, K. (2008). Lengua, nación e identidad: la regulación del plurilingüismo en España y América Latina, Iberoamericana Editorial Vervuert, Madrid.

Vargas Llosa, M. (2009). Sueño y realidad de América Latina, Fondo Editorial de la Pontificia Universidad Católica del Perú, Lima.

Zanatta, L. (2012). Historia de América Latina. De la colonia al siglo XXI (trad. Alfredo Grieco y Bavio, Guillermo David), Siglo Veintiuno Editores, Buenos Aires. 